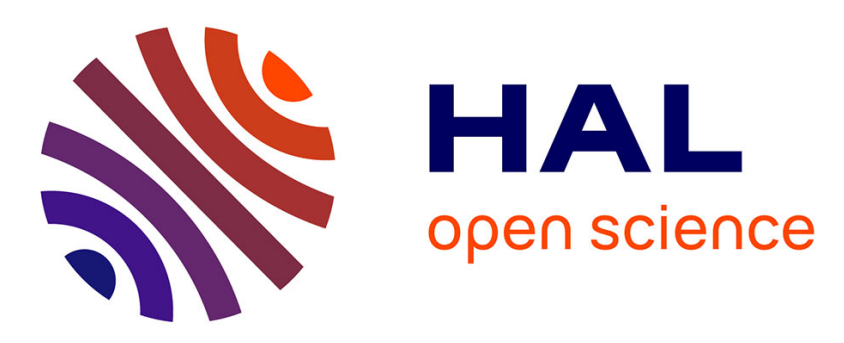

\title{
Domestic wastewater treatment with emergent hydrophyte beds in France
}

\author{
A. Liénard, Catherine Boutin, D. Esser
}

\section{To cite this version:}

A. Liénard, Catherine Boutin, D. Esser. Domestic wastewater treatment with emergent hydrophyte beds in France. IAWPRC International conference on the use of constructed wetlands in water pollution control, Cambridge, GBR, 24-27 September 1990, Sep 1990, Cambridge, United Kingdom. pp.183-192. hal-02575108

\section{HAL Id: hal-02575108 \\ https://hal.inrae.fr/hal-02575108}

Submitted on 26 May 2021

HAL is a multi-disciplinary open access archive for the deposit and dissemination of scientific research documents, whether they are published or not. The documents may come from teaching and research institutions in France or abroad, or from public or private research centers.
L'archive ouverte pluridisciplinaire HAL, est destinée au dépôt et à la diffusion de documents scientifiques de niveau recherche, publiés ou non, émanant des établissements d'enseignement et de recherche français ou étrangers, des laboratoires publics ou privés. 
90/0042Proceedings of the InwPre internatived 9010042 conf. on the use of cousturted vetlands in water polleition contual, 19 cambidge, GBR
24.27 sept. 1990,192

\title{
DOMESTIC WASTEWATER TREATMENT WITH EMERGENT HYDROPHYTE BEDS IN FRANCE
}

\author{
A. Liénard, C. Boutin and D. Esser \\ CEMAGREF - Division Qualité des Eaux Pêche et Pisciculture, \\ 3, Quai Chauveau 69336 - Lyon Cedex 09, France
}

\section{ABSTRACT}

CEMAGREF has been studying Emergent Hydrophyte Treatment systems (EHTS) since 1983 on three experimental sites. Two of them can be considered as typlcal for the Max-Planck-Institute Process (MPIP) as developed by Dr. Seldel, regarding their general layout with the succession of five treatment stages in cascade planted with different Emergent Hydrophyte species. The performance of one of these two plants (Salnt Bohalre), designed by Dr.seidel herself, proved that it is possible to feed the drained beds (1=t and 2nd stages), planted with reeds and alternately fed, with raw sewage at high loading rates without the occurence of clogging. However, It also showed that the last three stages, continuously fed, were not sufficientiy oxygenated and clogged rapldiy. This fallure was also confirmed in Pont-Rémy although this plant is underloaded. The performance of the first stage beds could be improved further by the use of batch feeding (intermittent feeding), by increasing the height of the filter media and by choosing a more adequate granulometry. Alternately fed percolation flow beds can also be used as a first stage of treatment followed by wastewater stabilization ponds. The example of Gensac la Pallue shows that they can remove $85 \%$ of the suspended solids and $70 \%$ of the organlc load, at a loading rate of 30 to $35 \mathrm{~g}$ of BODo per square metre. Such a combined system can thus provide an efficlent and reliable treatment requiring a specific surface reduced by 40 \% as compared to wastewater stabilization ponds only.

\section{KEYWORDS}

Wastewater treatment; Reed beds; Percolation flow; Alternative feeding; Batch feeding; Gravel media; Wastewater stabilization ponds.

\section{INTRODUCTION}

"Rustic" and rather simple wastewater treatment systems for small communities in rural areas have been a major interest of CEMAGREF for a long time. CEMAGREF ' has largely contributed to the development of wastewater stablilzation ponds (WSP). Today, there exist about 2000 WSP in rural France. However, WSP cannot be regarded as the solution in all cases. In particular, the surface required In France, we calculate $10 \mathrm{~m}$ for one p.e. - and the necessary tightness of the underlying soli might exclude the cholce of wsP. Therefore CEMAGREF is also looking for alternatives to WSP, with the same degree of rusticlty and simplicity in order to widen the cholce for rural communities. 
SAINT BOHAIRE (LOIr et Cher)

For the reasons gust mentioned, two small wastewater treatment plants at a boarding school, constructed In 1978 and 1982 under the direct advice of Dr. seidel, attracted our attention. The flrst one not belng very heavily loaded, 1t was especlaliy the second plant which was of great experimental interest. It has been already described elsewhere (Boutin, 1987).

We will gust recall here that it is a plant of a typical seldel design (Fig. 1), with at flrst 2 percolation bed stages, the first stage being composed of 4 parallel and alternately fed beds and the second one of 2 parallel beds also alternately fed, all planted with phragmites communis. Feeding time of each bed is 24 hours.

These flrst two stages are followed by 3 further horlzontal-flow stages, each one consisting of one bed, which was thus being continuously fed. On the 3 -d and $4^{\mathrm{th}}$ stages, the beds are planted with scirpus lacustris, whereas the 1 ast bed is planted with Iris pseudacorus.

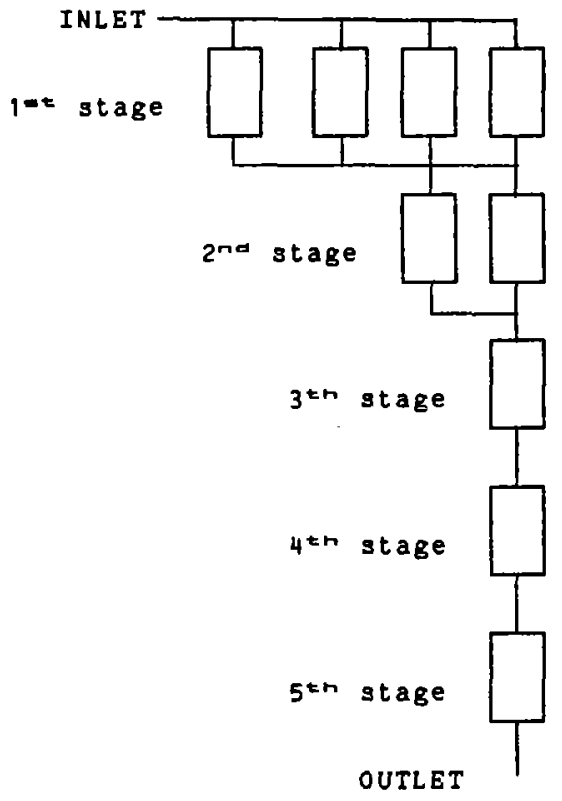

FIg. 1. Typlcal layout of a MPIP plant 
TABLE 1 General Description of the Second

Salnt-Bohaire Plant

\begin{tabular}{|c|c|c|c|c|c|c|c|}
\hline & & \multirow{2}{*}{$\begin{array}{c}\text { TYPE } \\
\text { OF } \\
\text { FLOW }\end{array}$} & \multirow{2}{*}{$\begin{array}{c}\text { NUMBEA } \\
\text { OF } \\
\text { BEDS }\end{array}$} & \multicolumn{3}{|c|}{$\begin{array}{l}\text { DIMENSION OF } \\
\text { EACH BED }\end{array}$} & \multirow{2}{*}{$\begin{array}{c}\text { EMERGENT } \\
\text { HYDROPHYTE } \\
\text { Species }\end{array}$} \\
\hline & & & & $\begin{array}{l}\text { Length } \\
(\mathrm{m})\end{array}$ & $\begin{array}{l}\text { WIdth } \\
(m)\end{array}$ & $\begin{array}{c}\text { Area } \\
\left(m^{2}\right)\end{array}$ & \\
\hline $1 \mathrm{st}$ & Stage & Percolation & ${ }^{4}$ & 5.0 & 1.5 & 7.5 & $\frac{\text { Phragmites }}{\text { commun1s }}$ \\
\hline 2 nd & Stage & Percolation & $\stackrel{2}{\text { paralle } 1}$ & 5.0 & 1.5 & 7.5 & $\frac{\text { Phragmites }}{\text { communis }}$ \\
\hline $3^{\text {nd }}$ & Stage & Horlzontal & 1 & 4.0 & 1.5 & 6.0 & $\frac{\text { sc1rpus }}{\text { lacustris }}$ \\
\hline $4 \in n$ & Stage & Horizontal & 1 & 4.0 & 9.5 & 6.0 & $\frac{\text { Sclrpus }}{\text { lacustr } 1 \mathrm{~g}}$ \\
\hline $5=n$ & Stage & Horizontal & 1 & 4.0 & 1.5 & 6.0 & $\frac{\operatorname{Ir} 1 \mathrm{~s}}{\text { pseudacorus }}$ \\
\hline
\end{tabular}

The beds of the percolation stages are filled with a $45 \mathrm{~cm}$ high layer of gravel, with an increasing granulometry from top to bottom (F1g. 2), whereas the beds of the horizontal flow stages are filled by a uniform $30 \mathrm{~cm}$ of pea gravel (FIg. 3).

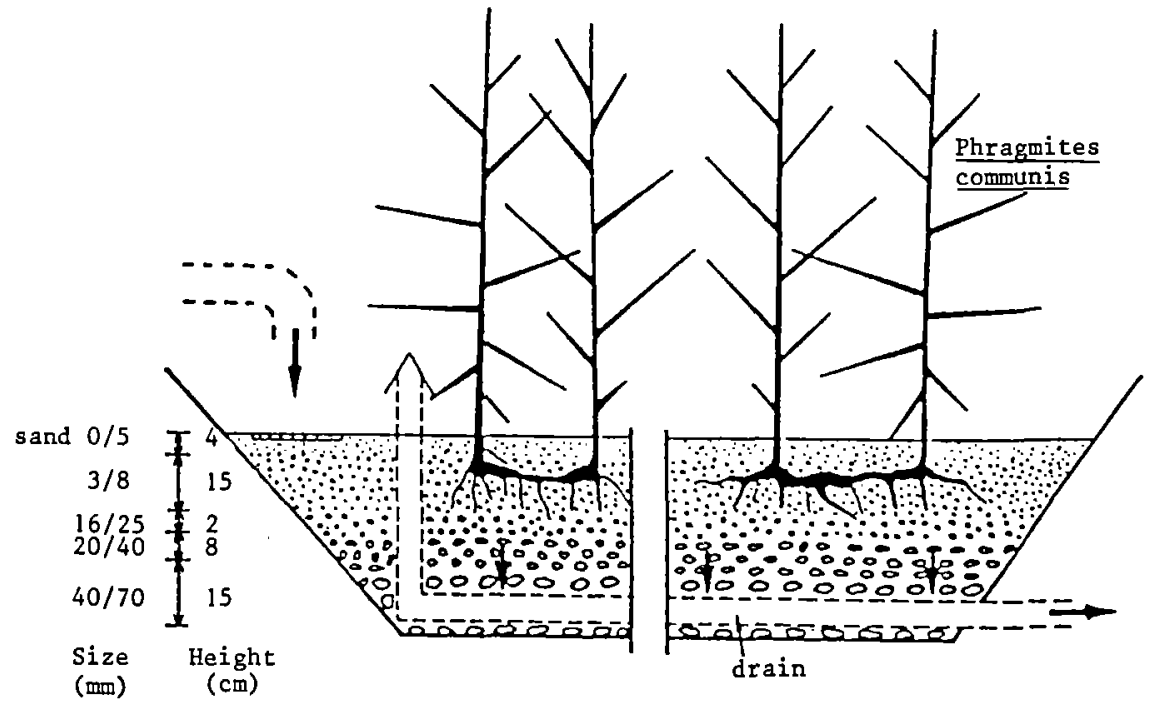

Fig.2. Schematic cross section of a percolation flow bed. 


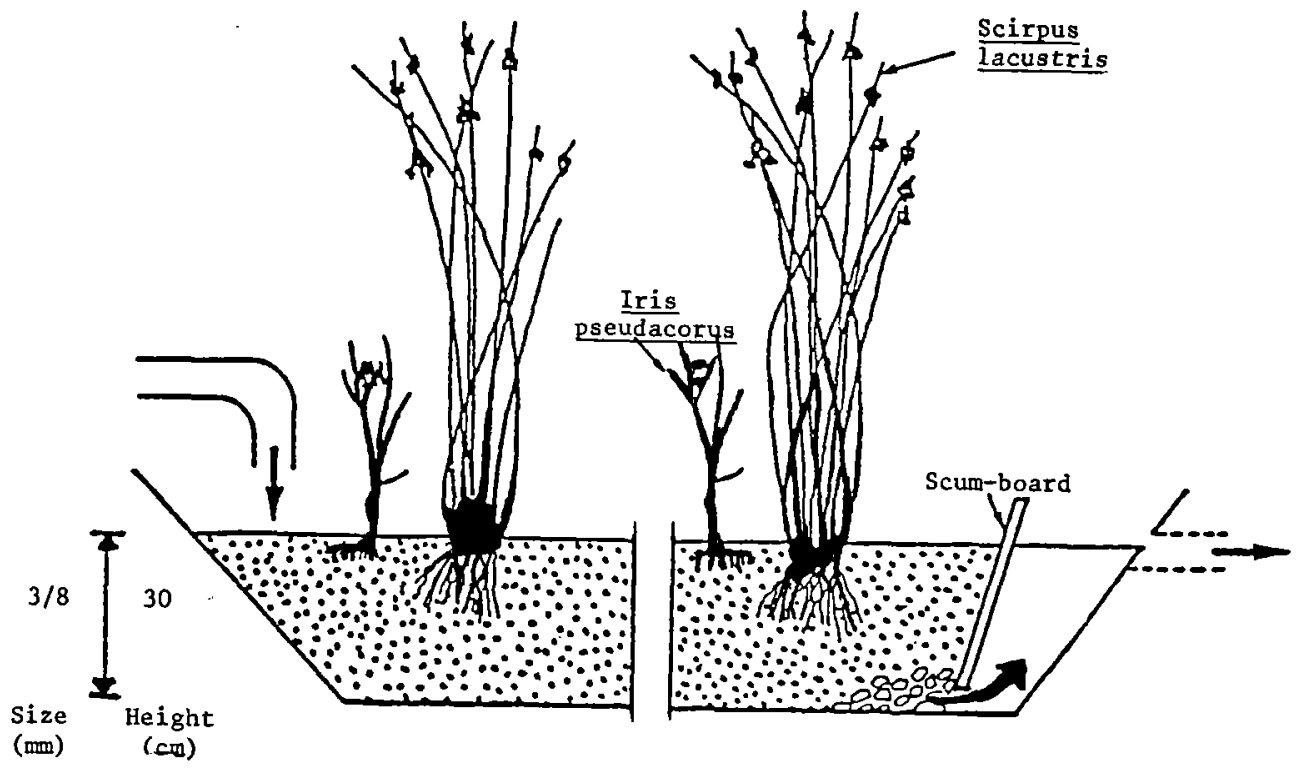

Fig.3. Schematic cross section of an horizontal flow bed.

The size of the plant $1 \mathrm{~s} 63 \mathrm{~m}^{2}$ and our measuring has revealed a heavy organic and nydraulic loading during the time of school activities, but a light load $1 \mathrm{~s}$ applied during week-ends and holldays. Mean organic loading was about (in $g$ $\left.n^{-2} d a y^{-1}\right)$ :

$$
\text { COD }: 45: 3,8 O D=20 \quad \text { SS }: 15
$$

Related to the total area of the four beds of the rirst $s$ tage $\left(30 \mathrm{~m}^{2}\right)$, the organic loading would be (In 8 m-z day-1) :

$$
\begin{array}{llll}
C O D: 94.5 & B O D=: 42 & \text { TP }: 1.9 & \text { SS }: 31.5 \\
K N: 8.0 & &
\end{array}
$$

The mean hydraulic loading $1365 \mathrm{~mm} / \mathrm{day}$, which corresponds, according to our new defintion (Pujol and Lienard, 1989) to about $2 \mathrm{~m}^{2} / \mathrm{person}$ equivalent for the entire surface area of the system.

On the basis of nine weasuring campalgns, the mean abatements were:

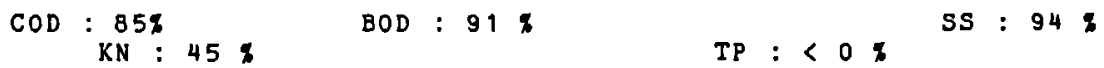

The monitoring of the plant also revealed a great efficlency of the $1=t$ stage beds, which are able to accept very hlgh loads of concentrated raw wastewater.

The second stage, however, was not as efficlent, which we think is partly due to the fact that the suspended solids have already been retalned on the ist stage and the granulometry, belng Identical on the 2nd stage, does not permit a further flitration. The other reason is that the rather coarse gravel of the underlying layers has a relatively small specific surface for fixing active bacterlat blomass. 
The three last stages, always continuously fed, quickly showed signs of clogging, even though there were hardly any more suspended solids in the arriving wastewater. Samples of gravels taken out of these beds presented nauseous odours typlcal for an anaerobic environment; organic matter was poorly mineralized and had a gelatinous aspect. Redox potential was always Included between - 50 and $+100 \mathrm{mV} / \mathrm{NHE}$. It $1 \mathrm{~s}$ known from sand fliter systems that bacterla in anaerobical conditions produce mucus silmes rich in polysaccharides (Kristiansen, 1981) which provoke the clogging mechanlsm by fliling the macroporosity. Inls induces surface flow and consequently poor performance. But our first hypothesis was that this disfunctioning was mainly due to periodical overloading during winter time, when school activity. Is most Important.

This inclted us to construct a similar system on another site with more regular sewage inflow. Another reason for the construction of this new plant was the fact that we wanted to test longer feeding and rest perlods on the first "stages, and that this requires higher freeboards as some ponding occurs at the end of the feeding period (beds in saint Bohalre are made of glassfibre which cannot be easily modifled). We think that longer rest periods are necessary to achleve good mineralization of primary sludges.last but not least, a new construction should also give us indications about the costs of building guch a system.

\section{PONT-REMY (SOMme)}

Pont-Rémy is thus almost a larger scale replica of the saint Bohalre plant with its good and bad sldes. However, for the first two upper layers of the percolation stages and for the horizontal rlow stages the graln gize was modifled: we thought that a coarser upper layer of the percolation stages would facilitate drying and subsequent mineralization of the flltered primary sludges during rest perlods and that coarger materlals in the horlzontal flow beds mlght prevent clogging. Thls plant has also already been briefly described elsewhere (Liénard, 1987).

Only half of the beds of the first two stages were put into operation, yet the loadg applied per surface area of these beds are still lower than in salnt Bonalre due to a delay in the construction of the munlclpal sewerage system. The organic loads collected were respectively ( 1 n $g m^{-2}$ day-1):

$$
\begin{aligned}
& \text { COD : } 18.2 \quad B O D: 6.4 \\
& \text { NK : } 2.2 \\
& T P: 0.5^{\text {SS }: 4.8}
\end{aligned}
$$

The beds were fed for 48 hours (or 72 hours during weekends) whlch left a rest perlod of 7 days for the other 3 beds. We could not however determine wether the better mineralization of primary sludges in Pont-Remy was due to these longer rest perlods or due to the relatively low loads applied.

Two of the four beds in operation at the first stage were planted with Glyceria aquatica and one bed remalned unplanted. Glycerla, although it showed a good second growth, proved to be 111 -adapted due to growth in dense clusters and poor surface colonization. The unplanted bed showed long periods of ponding. -but we could not measure any differences in treatment efficlency with our I Imlted investigations on this aspect. The Phragmites from natural wetlands planted in small clumps into one of the beds in April 87 developed well and the inflitration surface in this bed has the best aspect and shows no slgns of clogging. Earlier plantings from seedilngg bought from an horticulturist were not successful in the coarse material of the beds.

On the second stage the treatment efflclency was low again, because we repeated the same error made in salnt Bohalre, that is not to choose a finer filling material on the second stage beds than on the first stage Deds. The absence of the fliter effect of disposed primary sludge causes very rapid infiltration on these beds, using only 40 to 60 of their gurface area. 
On the last stages, the same clogging problems as in salnt Bohaire occurred soon, even in the absence of high loading peaks. We tried to improve the aeration of these beds by instaliing siphons on the outflow, in order to drain the beds in Intervals related to the flow. However, due to the topography, we could not create a hydraulic gradient sufficient to empty the beds significantiy. In Salnt Bohalre. we later installed similar siphons: we noticed an increased oxygenation of the media but nevertheless apparentiy this was Insurficient to prevent clogging. Most likely, a complete drying of the beds $1 \mathrm{~s}$ needed. Maybe the roots of scirpus have a clogging effect as well.

The production of plant blomass on these last stages is very lmportant and necesgltates blannual cutting, if one wants to prevent pollution by decaying organlc matter. The supplementary management constralnt of biannual cutting has no advantage for the elimination of nutrients, as quantities exported with the plant blomas are negligible compared to the loads applied in such systems.

Based on one complete measurement campalgn of 48 hours ouring the sumer season, the abatement of pollution was as follows:

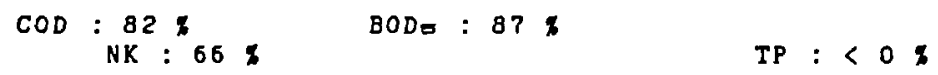

Random samples were. taken regularly by qualified staff. effluent diuality was always satisfactory. However, we are inclined to think that the $111-f$ unctioning of the last three stages would have had a more marked negatlve Influence, had the plant been fed at its rull permissible load with all beds in operation on the first two stages.

Construction costs of the Pont-Remy plant were, in 1986 : 1650 FF/p.e., considering that reinforced concrete beds were chosen.

\section{GENSAC LA PALLUE (charente)}

The small townshlp of Gensac la Pallue (1700 Inhabltants) had to extend its or 1 ginal treatment faclilties composed of two wastewater stabilization ponds while being limited by avallable space. This was the opportunity for us to propose a first step of treatment by reed beds. For dimensioning these beds we used the loads applied to the flrgt stage of the second plant in Saint Bohaire. Thus, we were able to test the performance of such beds under high but regular loading. For topographlcal reasons and in order to achleve a good surface digtrlbution through a hlgh instantaneous hydraulic load, we chose 8 parallel beds in one stage (Fig. 4). Also a third pollshing pond was added. 


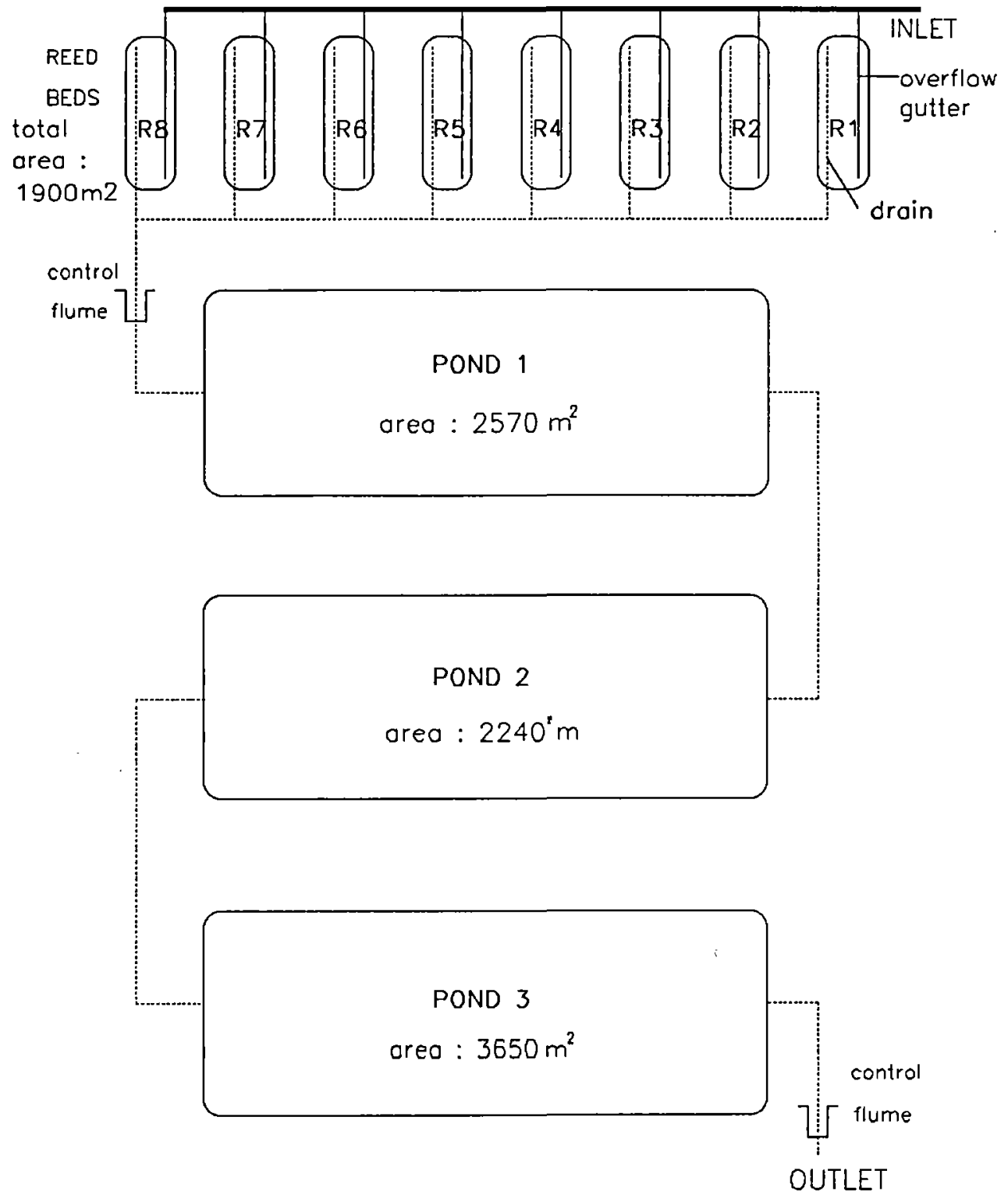

Fig. 4. Schematic description of the Gensac plant.

This allowed a total dimensionlng of approximately $6 \mathrm{~m}^{2}$ p.e.-1:

- about $1 \mathrm{~m}^{2}$ p.e.-1 for the reed filters;

- and about $5 \mathrm{~m}^{2}$ p.e.-1 for the USP (Instead of $10 \mathrm{~m}^{2}$ normally required).

The watertightness of the reed fliters was achleved by puddled clay, found in the vicinity. The granulometry of the fliling is ldentical with that in saint Bohalre, except that there is no flrst upper layer of sand. As mentioned before, we think that a coarser materlal will lmprove the drylng of the primary sludge. The total helght of the beds $1 \mathrm{~s}$ about $50 \mathrm{~cm}$ (Fig. 5). 


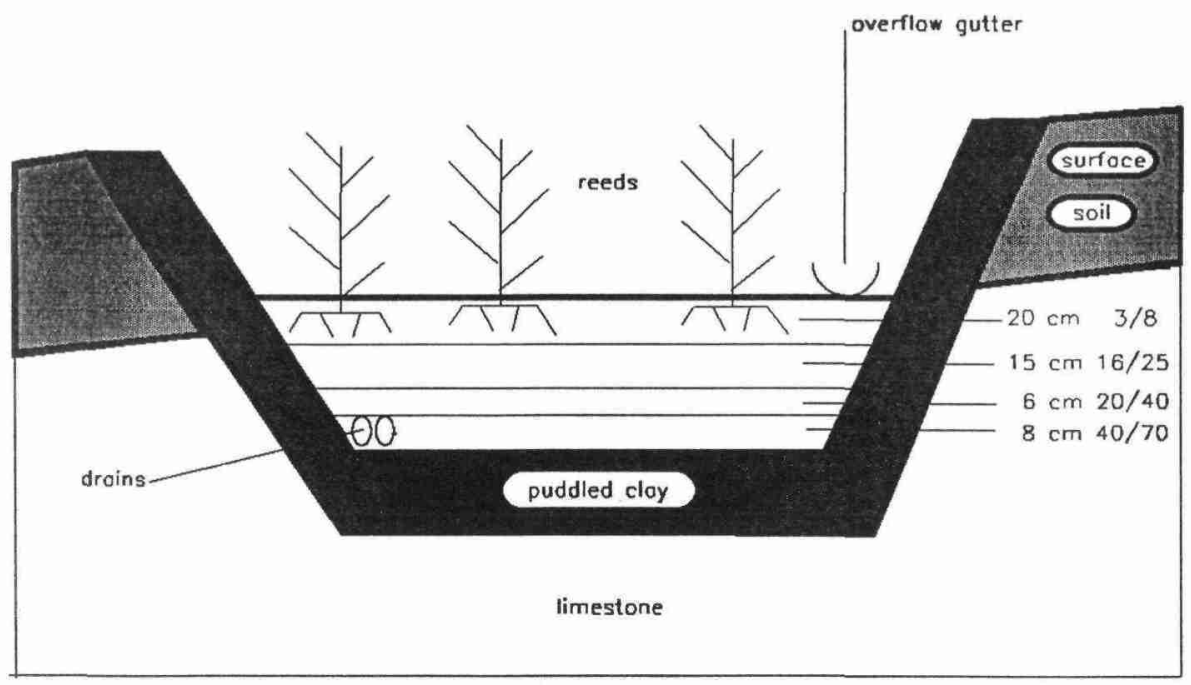

Fig. 5, Schematic cross section of a reed bed in Gensac.

The feeding of the beds is for 24 hour periods ( 72 hours during weekends). The rest period was thus 9 days and each bed is fed during the weekends alternatively once in 8 weeks.

Since June 1987, the loads applied are as follows (in $\mathrm{kg} \mathrm{d}^{-1}$ ) :

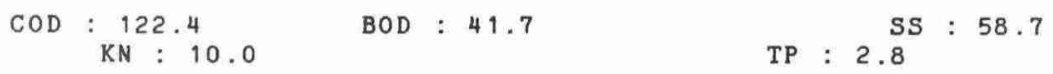

Based on the total area of the reed beds, this represents the following loads (in $g \mathrm{~m}^{-\mathrm{z}}$ ) :

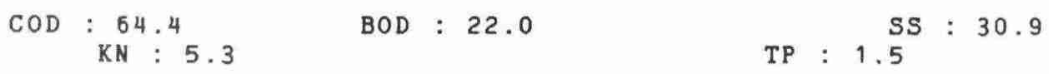

The change in the concentrations is shown on Table 2.

TABLE 2 Change in the Concentrations (mg * $1^{-1}$ )

\begin{tabular}{|c|c|c|c|}
\hline & Raw influent & Reed bed eff 1 . & Final effluent \\
\hline COD & $\begin{array}{c}720 \\
(554-820)(6)\end{array}$ & ${ }^{245}(92-400)(14)$ & $\begin{array}{r}75 \\
(48-128)\end{array}$ \\
\hline BOD & $\begin{array}{c}245 \\
(210-280) \quad(4)\end{array}$ & $(35-155)^{77}$ (9) & $(6-16)^{11}$ \\
\hline SS & $\begin{array}{c}345 \\
(310-392) \quad(6)\end{array}$ & $(20-123)^{50}(14)$ & $(<5-20)^{11}(10)$ \\
\hline $\mathrm{KN}$ & $(35-80)^{58.5}(6)$ & $\begin{array}{c}54.2 \\
(21.5-69)\end{array}$ & $(15-51)^{26.4}$ (9) \\
\hline$T P$ & $(13-22)^{16.7}(6)$ & $(5.3-18.0)^{11.8}(11)$ & $\begin{array}{c}6.4 \\
(4.25-10.5) \quad(5)\end{array}$ \\
\hline
\end{tabular}


TABLE 3 Elimination on Reed Beds in 2

\begin{tabular}{|l|ll|lc|cc|c|}
\cline { 2 - 8 } \multicolumn{1}{c|}{} & \multicolumn{2}{|c|}{ September 88} & \multicolumn{2}{|c|}{ March 89} & \multicolumn{2}{c|}{ June 89 } & Mean \\
\hline COD & 66 & 68 & 77 & 66 & 67 & 67 & 68 \\
BOD & 68 & 70 & 74 & - & 70 & - & 70 \\
SS & 87 & 84 & 87 & 84 & 86 & 86 & 85 \\
\hline
\end{tabular}

\begin{tabular}{|l|lr|rr|rr|}
\hline KN & 20 & 20 & 31 & 25 & 36 & 43 \\
TP & 34 & 4 & 25 & 16 & 26 & 31 \\
\hline
\end{tabular}

He observed little varlation in the removal of COD, $B O D=$ and $S S$ but a high varlablilty in the removal of total phosphorus and Kjeldahl nltrogen.

In April 1989, we also measured the bacterlologlcal elimination of the treatment plant in Gensac, the results are given on Table 4 (in units per $100 \mathrm{mll}$.

\begin{tabular}{|c|c|c|c|c|}
\hline & \multirow{2}{*}{$\begin{array}{c}\text { Raw } \\
\text { Influent }\end{array}$} & \multicolumn{2}{|c|}{ After reed beds } & \multirow{2}{*}{$\begin{array}{c}\text { Effluent } \\
\text { after } \\
\text { ponds }\end{array}$} \\
\hline & & $\begin{array}{l}\text { Bed } \\
\text { working }\end{array}$ & $\begin{array}{c}\text { Bed working } \\
\text { the day before }\end{array}$ & \\
\hline $\begin{array}{l}\text { Faecal } \\
\text { coliforms }\end{array}$ & $6.4 \times 10^{4}$ & $5.4 \times 10^{6}$ & $3.0 \times 10^{-0}$ & $<10^{=}$ \\
\hline $\begin{array}{l}\text { Faecal strepto- } \\
\text { coccus }\end{array}$ & $3.3 \times 10^{-}$ & $1.5 \times 10^{-6}$ & $2.8 \times 10^{4}$ & $\langle 10\rangle$ \\
\hline
\end{tabular}

The functioning of Gensac la Pallue showed that these type of beds are able to recelve rather concentrated $r$ aw wastewater without clogging. Together with the ponds, a satisfatory effluent quality was attained. Nitrogen and phosphorus retention on the reed beds was however low, although partly compensated by the ponds. Suspended sollds (algae) in the rinal effluent were very low ror wastewater stablitzation ponds due to the proliferation of Daphnia in the last pond, during a large perlod of the year. It has been proved that this type of treatment faclilty can be an adapted solution to improve the performance of overloaded ponds.

The total time needed for the malntenance of reed beds and ponds did not exceed 30 days per year. At present we are testing if we can reduce this further by dolng away with the cutting of the reeds, which accounts for 8 days per year.

\section{SAINT SYMPHORIEN DE LAY (LOIre)}

This plant is a sand filter consisting of 2 alternating beds fed with influent settled in primary sedimentation ponds. The helght of the sand beds $1 \mathrm{~s} 1.7 \mathrm{~m}$ and the beds were fed in weekly intervals. 
Although not being a macrophyte bed salnt symphorien allowed us to understand the Importance of intermittent or batch feeding.

We will not go into detalis about this plant, but just briefly present the Improvement of treatment efriciency brought about by the introduction of batch feeding ( $T a b l e ~ 5)$.

TABLE 5 Treatment Efficiency at Saint symphorien

\begin{tabular}{|c|c|c|}
\hline in & Before batch feeding & After batch reeding \\
\hline COD & 62.0 & 82.5 \\
SS & 56.0 & 92.0 \\
IN & 10.5 & 74.7 \\
IP & 10.4 & 77.0 \\
\hline
\end{tabular}

(respectively $5^{\mathrm{tm}}$ and $6^{\mathrm{th}}$ day of the cycle).

This shows that not only the COD abatement can be signiflcantly increased but also nitriflcation can be attalned. More surprisingly, phosphorus retention can also be Improved, provided an adequate substrate is chosen. Increased suspended solids retention is more difficult to explain.

This experience Inclted us to use batch feeding on the $1=$ stage of macrophyte beds in the future.

\section{CONCLUSIONS}

The reed bed systems monitored by CEMAGREF show that it $1 \mathrm{~s}$ possible to treat screened raw sewage on the first stage with a speciflc load of about $30-35 \mathrm{~g}$ of BODe per square metre per day, without clogging. However, the beds have to be well drained and alternately fed. A rest perlod of seven days seems to be necessary in order to achleve a good mineralization of the filtered primary sludges. An elimination of $85 \%$ of $5 S$ and 70 of the organic load 13 attalned. Most likely, their performance can be further lmproved by batch feeding.

We think that the suspended solids held back from the $r a w$ sewage on the Infiltration surface actualiy improve the filtration capacity and the microblologlcal activity on the well oxygenated surface of the reed beds. The reeds protect this mlcroblological activity from the negative effects of U.V. $11 \mathrm{ght}$ and rapid desiccation in summer and, to a lesser degree, of frost in winter.

The horlzontal flow beds whlch are continuously fed did not have a high efflclency and clogged rather rapidiy. In future plants, we will abollsh them and $11 \mathrm{mit}$ the new design to two stages of alternately fed percolation beds, all planted with reeds.

We also think to put pea gravel on the surface of the first stage beds and to decrease the granulometry of the lower layers as well as or the second stage beds and to increase the helght of the beds.

\section{REFERENCES}

Bout In, C. (1986). Domestic Wastewater Treatment in Tanks Planted with Rooted Macrophytes, Case study, Description of the system, Design Criterla, Efficlency. Post-Conference IAWPRC. P1rac1caba, Braz11, 24-27 August 1986. Wat. SC1. Tech., 19, No.12, PP.29-40.

Kristiansen, R. (1989). Sand-Filter Trenches for Purification of Septic Tanc Effluent : The Clogging Mechanism and Soll Physical Environment. $J$. Environm. Qual. 10, No.3, p. 353-364

Lienard, A. (1987). Domestic wastewater Treatment in Tanks with Emergent Hydrophytes, Latest Results of a Recent Plant in France. Wat. Scl. Tech. 19. No.12, P.373-375.

Pujol, R., Llénard, A. ( 1990$)$. Qualltative and Quantitative Characterlzation of waste water for Small Commulties, wat. Sci. Tech. 22, No. 3/4, pp 253-260. 